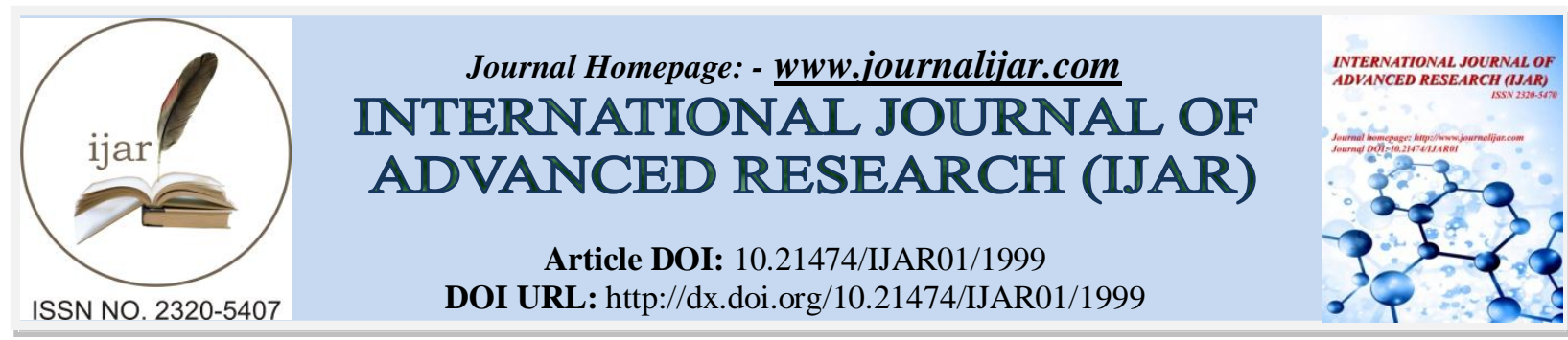

RESEARCH ARTICLE

\title{
STABILIZATION OF DUNE SAND MIXED WITH LDPE STRIPS FOR DESIGN OF EMBANKMENT IN CONSTRUCTION OF ROADS
}

Pankaj Kumar ${ }^{1}$, Vinit Das ${ }^{1}$, Akash Gupta ${ }^{1}$ and Dr. N.K. Ameta ${ }^{2}$.

1. M.E. Scholar, Dept. of Civil Engineering, M.B.M. Engg. College, J.N.V. University, Jodhpur, Rajasthan, India.

2. Professor, Dept. of Civil Engineering, M.B.M. Engg. College, J.N.V. University, Jodhpur, Rajasthan, India.

\section{Manuscript Info}

Manuscript History

Received: 26 September 2016

Final Accepted: 25 October 2016

Published: October 2016

Key words:-

Dune Sand, LDPE strips, Direct Shear, Permeability.

\section{Abstract}

Dune sand is widely present in western Rajasthan, India. It is loose in state, cohesion less and thus has a very low compressive strength. To make use of dune sand as a base material for construction of embankments for roads, it should be reinforced by mixing LDPE (low density polyethylene) strips in it. This study presents a simple way of recycling LDPE waste in the field of civil engineering as reinforcing material. Reinforced soil construction is an efficient and reliable technique for improving the strength and stability of soils. The technique is used in a variety of applications, such as, construction of road embankment. This paper describes an experimental study on mixing LDPE waste strips of size $5 \mathrm{~mm}$ X $5 \mathrm{~mm}$ with dune sand. The LDPE waste strips were mixed in percentage with dune sand as $0 \%$, $0.05 \%, 0.06 \%, 0.7 \%, 0.8 \%, 0.9 \%$ and $1.0 \%$. With this mix compositions, all the direct shear tests (DST) and variable head permeability tests were conducted at different dry densities arrived from standard proctor test as $1.57 \mathrm{gm} / \mathrm{cc}, 1.62 \mathrm{gm} / \mathrm{cc}$ and $1.66 \mathrm{gm} / \mathrm{cc}$ (M.D.D.). The results and conclusions were summed up which shows that use of LDPE waste in dune sand in an appropriate amount really improves the strength characteristics of the dune sand so that it becomes usable as a suitable material for construction of embankments for roads.

\section{Introduction:-}

Soil for a geotechnical engineer is the weathered material of earth crust, with or without organic matter. The bonding property of soil depends upon its particle size and is decreasing as the particle size increases. Dune sand has nil plasticity which means cohesion less, drainage fair with coefficient of permeability ranging between $10^{-4} \mathrm{~mm} / \mathrm{sec}$ to $10^{-2}$ $\mathrm{mm} / \mathrm{sec}$. Dune sand is found in abundance in Western Rajasthan, India. Large parts of Rajasthan, covering about 500,000 sq. kms, consist of desert soils which are wind-blown deposits. The sand dunes have an average height of about $15 \mathrm{~m}$. They are formed in highly arid conditions. Dune sand is non plastic and uniformly graded fine sand. It poses many geotechnical engineering problems. There are numerous geotechnical problems associated with dune sand. The reinforcing elements absorb the loads that might prevent the soil to fail in shear or due to excessive deformation. The stability and reliability of geotechnical structures can therefore be achieved by reinforcing the soil. Towards this end, randomly reinforcing the soil by using low density polyethylene strips obtained from waste plastic 
containers may provide an easy and sometimes an economical means to improve the engineering performance of soils. Many researchers like Maher and Ho (1994), Ranjan et al. (1996), Rao and Dutta (2004), Ameta et al. (2008), Amol S. Bale (2011), Pragyan Bhattari et. al. (2013), S. K. Tiwari et. al. (2013) and Akash Gupta (2016) have conducted investigation on stabilization of soils using different types of reinforcements.

\section{Materials Used For Present Study:-}

Dune Sand:-

Dune sand is found in abundance in western Rajasthan (India). The sand used in present study was brought from location near from Osian town, at about 65-70 km away from Jodhpur, Rajasthan on Jodhpur-Bikaner Highway. Dune sand is fine grained, uniform clean sand as per Unified Soil Classification System. Particle size ranges between $75 \mu$ to $4.75 \mathrm{~mm}$ which is fine to coarse sand, round to angular in particle shape as per Indian Standard Classification system.

\section{LDPE Sheets:-}

Low density polythene sheet of black color which is used as canal liner is used in the present study which has a thickness of 175 microns. The extent of polymerization of LDPE varies from product to product. It was also taken care that the film shall be uniform in color, texture and finish, substantially free from pin holes and undispersed raw materials, streaks and particles of foreign matter, no other visible defects such as melt fracture, holes, tears or blisters. Table 1 presents the properties of plastic waste material.

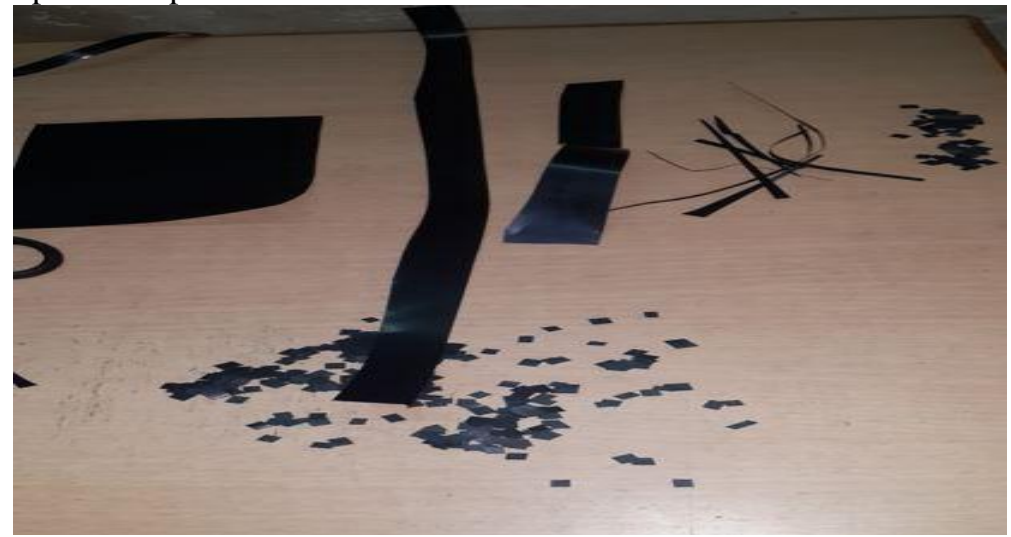

Table 1:- Properties of LDPE

Figure 1:- Plastic Waste Strips Used In The Study.

\begin{tabular}{|c|c|c|}
\hline S. No. & Property & Value \\
\hline 1. & Aspect ratio of strip $(1 / \mathrm{b})$ & 1.0 \\
\hline 2. & Thickness & 175 microns \\
\hline 3. & Density at $27^{\circ} \mathrm{C}(\mathrm{gm} . / \mathrm{cc})$ & 0.923 \\
\hline 4. & Melting point & $199^{\circ} \mathrm{C}$ \\
\hline
\end{tabular}

\section{Test Program and Procedure:-}

\section{Sieve Analysis or Particle Size Distribution Test:-}

The grain size distribution is found out by conducting sieve analysis test. The test was carried out with Indian Standard Sieve size $4.75 \mathrm{~mm}, 2.0 \mathrm{~mm}, 1.18 \mathrm{~mm}, 600 \mu, 300 \mu, 150 \mu, 75 \mu$, pan and weigh balance in the laboratory. In sieve analysis there is a nested column of sieve with wire mesh screen. A representative sample of $1000 \mathrm{gm}$ of dune sand have been taken for the analysis and poured into the top sieve which has the largest screen opening of $4.75 \mathrm{~mm}$. The sieves are arranged in descending order from top to bottom according to their opening size. The base is a round pan, called the receiver. The sample was shaken for 10 minutes on sieve shaker. After the shaking, the weight of material retained on each sieve was weighed. Percentage passing through each sieve was calculated and plotted against particle size. The cumulative percentage passing of the sample is found by subtracting the percent retained from $100 \%$. The particle size distribution curve plotted on semi-log scale is shown in Fig. 2. 


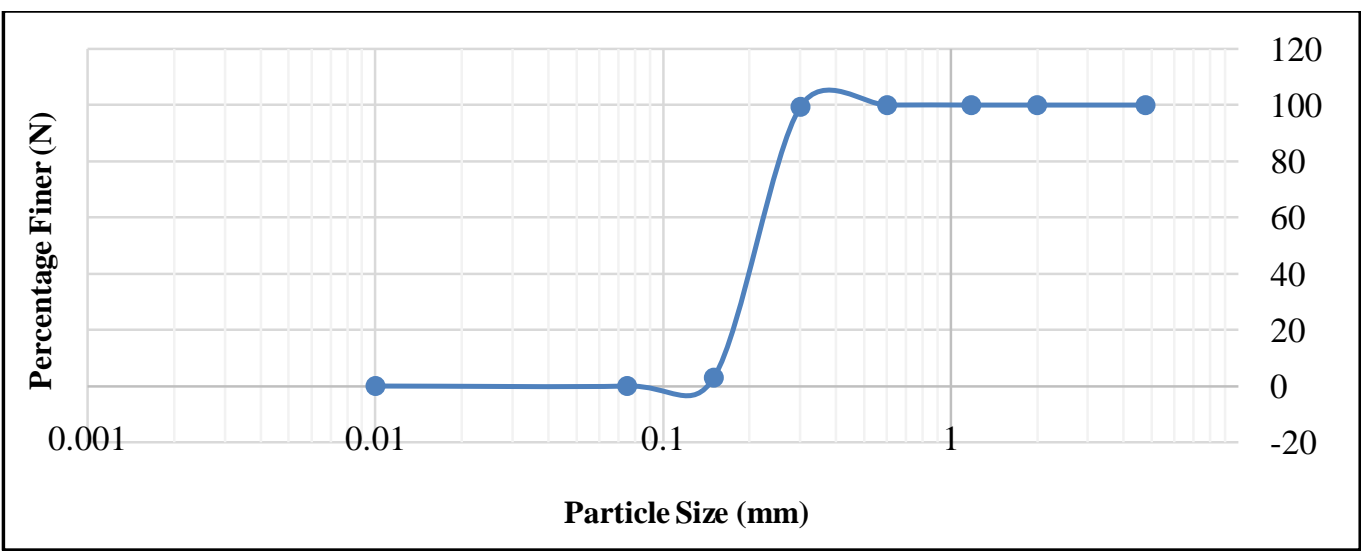

Figure 2:- Particle Size Distribution Curve

The properties found from the particle size distribution test are given in Table 2:

Table 2:- Properties of Dune Sand.

\begin{tabular}{|c|c|c|}
\hline S. No. & Property & Test Media (Dune Sand) \\
\hline 1. & Coefficient of uniformity $\left(\mathrm{C}_{\mathrm{u}}\right)$ & 1.43 \\
\hline 2. & Coefficient of curvature $\left(\mathrm{C}_{\mathrm{c}}\right)$ & 0.88 \\
\hline 3. & Mean Diameter $\left(\mathrm{D}_{50}\right)$ & $0.21 \mathrm{~mm}$ \\
\hline 4. & Effective size $\left(\mathrm{D}_{10}\right)$ & $0.16 \mathrm{~mm}$ \\
\hline 5. & Fine soil fraction $(75 \mu)$ & $0 \%$ \\
\hline
\end{tabular}

\section{Standard Proctor Test:-}

According to IS 2720 (Part VII), in the proctor test the mould recommended is of $100 \mathrm{~mm}$ diameter, $127.3 \mathrm{~mm}$ height and $1000 \mathrm{ml}$ capacity. About $3 \mathrm{~kg}$ of air dried samples were taken for the test. The soil is compacted by $25 \mathrm{blows}$ of the rammer of $2.6 \mathrm{~kg}$ mass, with a free fall of $310 \mathrm{~mm}$ and a face diameter of $50 \mathrm{~mm}$. the soil is compacted in three layers. The mould is fixed to a detachable base plate.

The result shows that initial decrease of dry density with addition of water is due to capillary tension which is not fully counteracted by the compacted effort and hold the particle in loose state resisting compaction. Dry density further increase with water content and then decrease with further increase in water content. The maximum dry density is obtained as $1.66 \mathrm{gm} / \mathrm{cc}$ at O.M.C $12.34 \%$. Two more dry densities as $1.57 \mathrm{gm} / \mathrm{cc}$ and $1.62 \mathrm{gm} / \mathrm{cc}$ were considered for the present study.

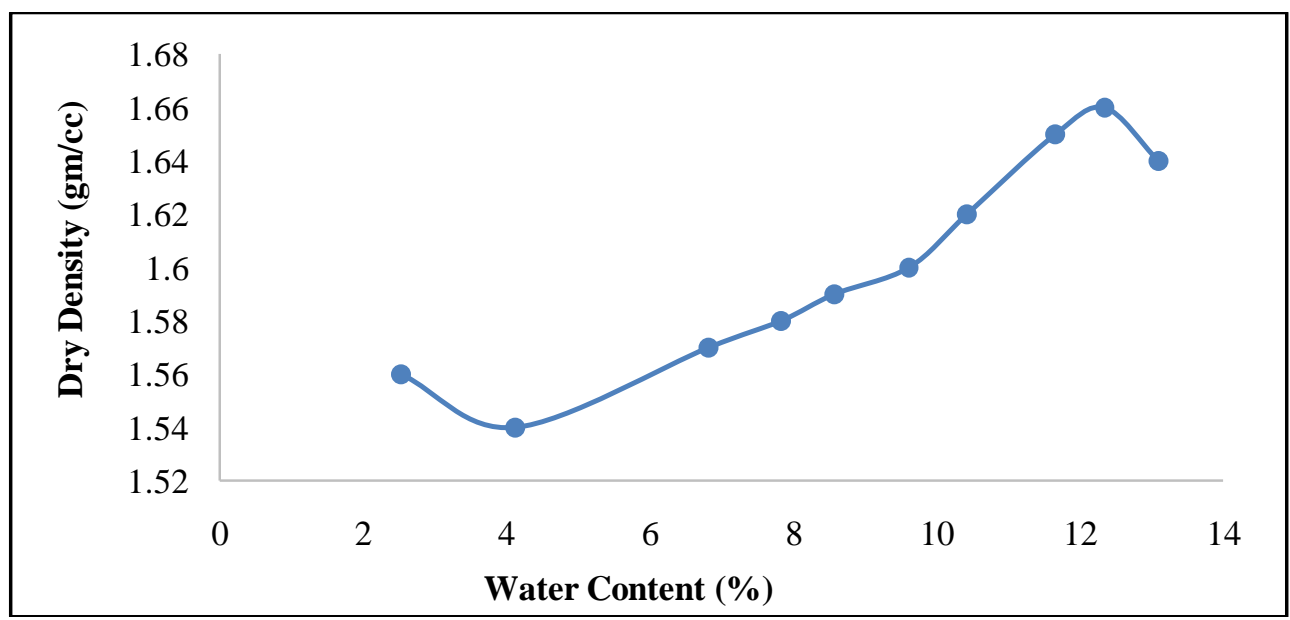

Fig 3:- Dry Density v/s Water Content Curve.

\section{Direct Shear Test:-}

The value of cohesion (c) and the angle of internal friction $(\phi)$ of the soil are found by direct shear test. These are the soil shear strength parameters. Direct shear test was performed on dune sand and mix compositions with LDPE 
waste with a strain controlled shear apparatus at a rate of strain of $1.25 \mathrm{~mm}$ per minute in accordance with IS 2720 (Part XIII). The test was conducted by putting the dune sand at three different dry densities inside the shear box which is made up of two independent parts. A constant normal load is applied to obtain one value of $\mathrm{c}$ and angle of internal friction $(\phi)$. Horizontal load (shearing load) is increased at a constant rate and is applied till the failure point is reached. The equation to calculate the value of shear strength ' $\tau$ ' is as follows:

$$
\tau=\mathrm{c}+\sigma \tan (\phi)
$$

After repeating the experiment for different normal loads we obtain a plot which is a straight line with slope equal to angle of internal friction $(\phi)$ and intercept equal to the cohesion (c). Cohesion for dune sand is zero, hence here (c) becomes zero. Direct shear test is the easiest and the quickest way to determine the shear strength parameters of a soil sample.

\section{Comparative Study:-}

From the results, it can be seen that the value of friction angle increases to a certain limit and then decreases as the value of LDPE waste content increases in the dune sand. Shear stress increases and then decreases in the same manner. The maximum values have been obtained at $0.06 \%$ of LDPE waste content. To obtain better results in practice, the value of LDPE waste content should be low. That will provide more strength to dune sand. It has been found from the study that on keeping dry density as constant, the shear stress of the mix composition increases as the normal stress increases. The results of direct shear test are tabulated in Tables 3, 4, 5 and in Fig. 4, 5, and 6.

Table 3:- Variation of Shear Stress with Normal Stress for Mix Composition at MDD 1.66 gm/cc.

\begin{tabular}{|c|c|c|c|c|c|c|}
\hline \multirow{2}{*}{$\begin{array}{c}\text { Normal } \\
\text { Stress } \\
\left(\mathrm{kg} / \mathrm{cm}^{2}\right)\end{array}$} & \multicolumn{7}{|c|}{ Shear Stress $\left(\mathrm{kg} / \mathrm{cm}^{2}\right)$} \\
\cline { 2 - 7 } & $\begin{array}{c}0.05 \% \\
\text { Admixture } \\
\end{array}$ & $\begin{array}{c}0.06 \% \\
\text { Admixture } \\
(\mathrm{DS} 1)\end{array}$ & $\begin{array}{c}0.7 \% \\
\text { Admixture } \\
(\mathrm{DS} 2)\end{array}$ & $\begin{array}{c}0.8 \% \\
\text { Admixture } \\
(\mathrm{DS} 4)\end{array}$ & $\begin{array}{c}0.9 \% \\
\text { Admixture } \\
(\mathrm{DS} 5)\end{array}$ & $\begin{array}{c}1.0 \% \\
\text { Admixture } \\
(\mathrm{DS} 6)\end{array}$ \\
\hline 0.5 & 0.5958 & 0.6050 & 0.6325 & 0.5866 & 0.6508 & 0.6325 \\
\hline 1.0 & 1.0725 & 1.1000 & 1.1183 & 1.0540 & 1.1091 & 1.0266 \\
\hline 1.5 & 1.4758 & 1.6130 & 1.6040 & 1.4941 & 1.5308 & 1.4578 \\
\hline
\end{tabular}

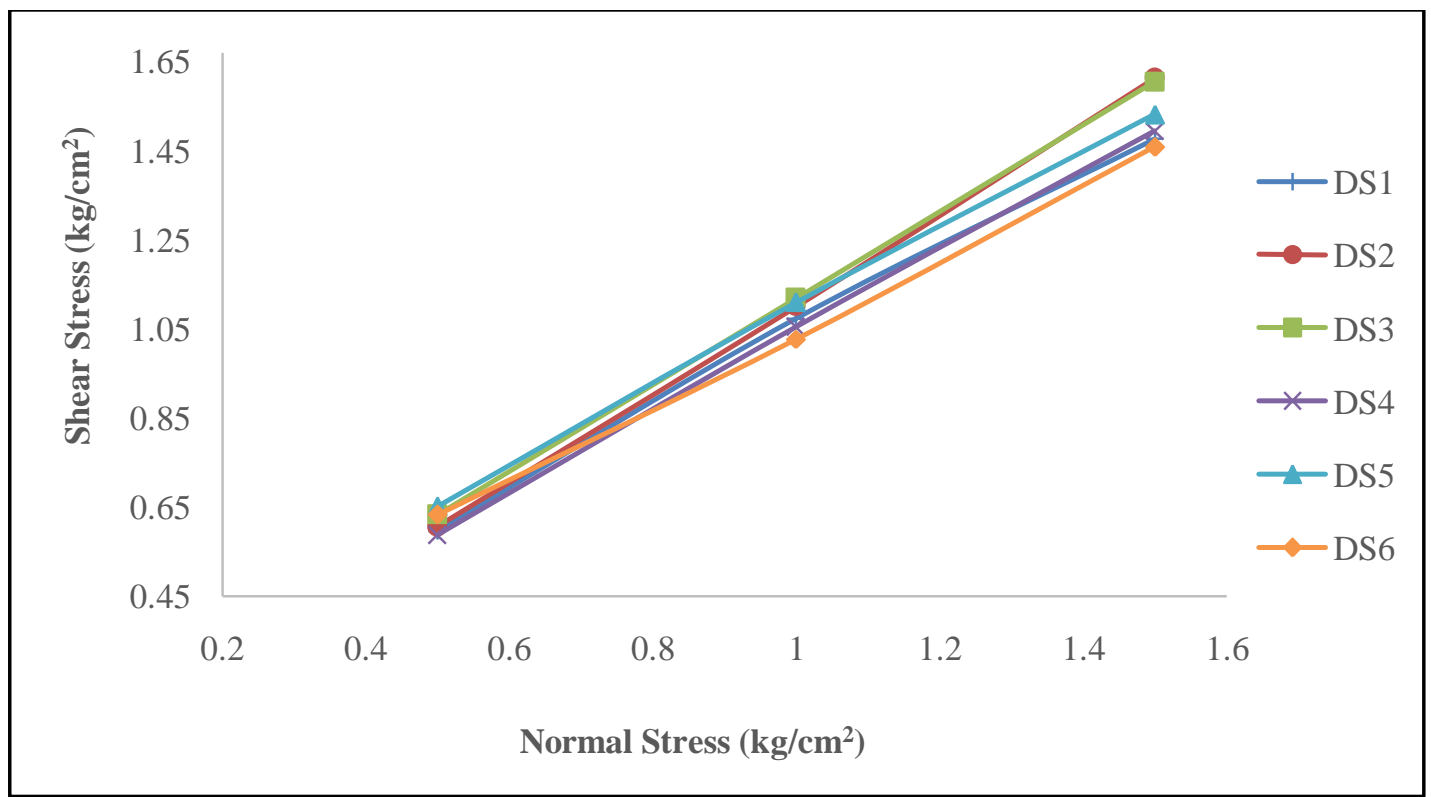

Figure 4:- Variation of Shear Stress with Normal Stress for Mix Compositions at MDD 1.66 gm/cc.. 
Table 4:- Variation of Shear Stress with Normal Stress for Mix Compositions at Dry Density $1.62 \mathrm{gm} / \mathrm{cc}$.

\begin{tabular}{|c|c|c|c|c|c|c|}
\hline \multirow{2}{*}{$\begin{array}{c}\text { Normal } \\
\text { Stress } \\
\left(\mathrm{kg} / \mathrm{cm}^{2}\right)\end{array}$} & \multicolumn{7}{|c|}{ Shear Stress $\left(\mathrm{kg} / \mathrm{cm}^{2}\right)$} \\
\cline { 2 - 7 } & $\begin{array}{c}0.05 \% \\
\text { Admixture } \\
\end{array}$ & $\begin{array}{c}\text { Mix Composition } \\
\text { Admixture } \\
(\mathrm{DS} 7)\end{array}$ & $\begin{array}{c}0.7 \% \\
\text { Admixture } \\
(\mathrm{DS} 9)\end{array}$ & $\begin{array}{c}0.8 \% \\
\text { Admixture } \\
(\mathrm{DS} 10)\end{array}$ & $\begin{array}{c}0.9 \% \\
\text { Admixture } \\
(\mathrm{DS} 11)\end{array}$ & $\begin{array}{c}\text { Admixture } \\
(\mathrm{DS} 12)\end{array}$ \\
\hline 0.5 & 0.4767 & 0.4950 & 0.5591 & 0.4675 & 0.5133 & 0.5866 \\
\hline 1.0 & 0.9441 & 0.9534 & 1.0450 & 0.8800 & 0.9075 & 1.0083 \\
\hline 1.5 & 1.3841 & 1.4483 & 1.4758 & 1.3016 & 1.3291 & 1.3933 \\
\hline
\end{tabular}

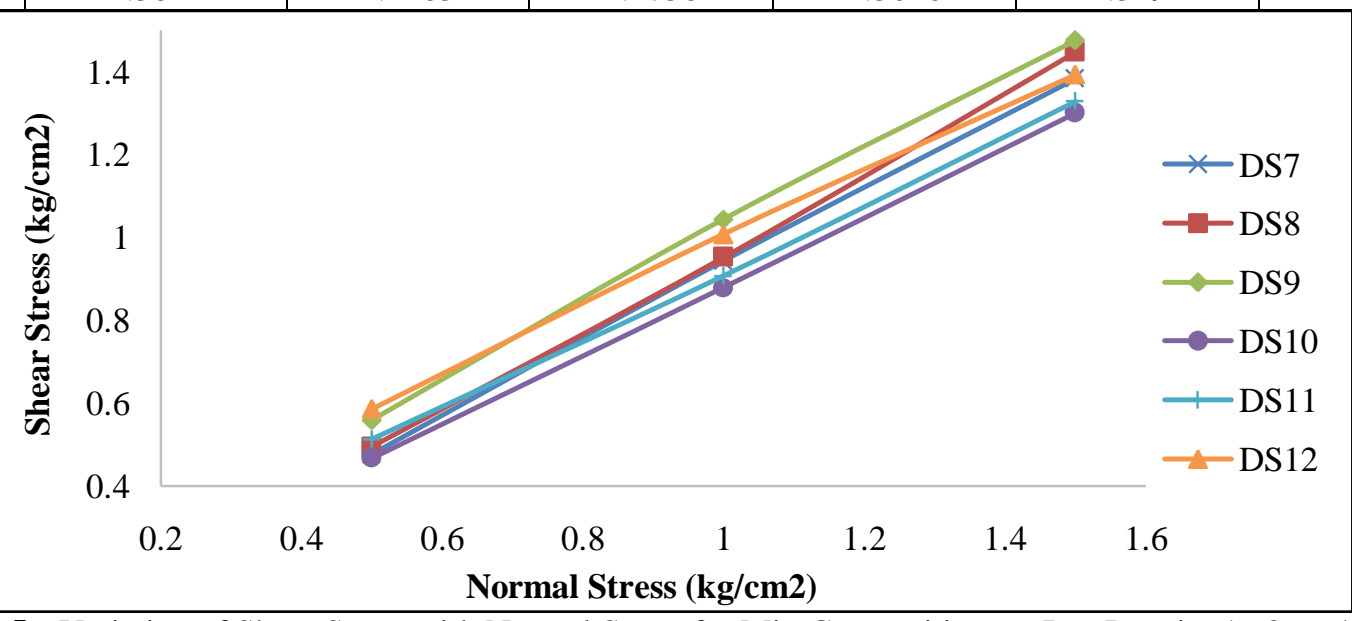

Figure 5:- Variation of Shear Stress with Normal Stress for Mix Compositions at Dry Density $1.62 \mathrm{gm} / \mathrm{cc}$

Table 5:- Variation of Shear Stress with Normal Stress for Mix Compositions at Dry Density1.57 gm/cc



Figure 6:- Variation of Shear Stress with Normal Stress for Mix Compositions at Dry Density $1.57 \mathrm{gm} / \mathrm{cc}$.

Values of friction angle for different dry densities and values of different percentages of LDPE waste content are given in Table 6 and Fig. 7. 
Table 6:- Variation of Friction Angle for different Dry Densities with Different Percentages of Plastic content.

\begin{tabular}{|c|c|c|c|c|c|c|c|}
\hline \multirow{2}{*}{$\begin{array}{c}\text { Dry } \\
\text { Density } \\
(\mathrm{gm} / \mathrm{cc})\end{array}$} & \multicolumn{7}{|c|}{ Angle of Internal Friction $\phi$ (Degree) } \\
\cline { 2 - 8 } & $\begin{array}{c}0 \% \\
\text { Admixture }\end{array}$ & $\begin{array}{c}0.05 \% \\
\text { Admixture }\end{array}$ & $\begin{array}{c}0.06 \% \\
\text { Admixture }\end{array}$ & $\begin{array}{c}0.7 \% \\
\text { Admixture }\end{array}$ & $\begin{array}{c}0.8 \% \\
\text { Admixture }\end{array}$ & $\begin{array}{c}0.9 \% \\
\text { Admixture }\end{array}$ & $\begin{array}{c}1.0 \% \\
\text { Admixture }\end{array}$ \\
\hline 1.66 & $33.42^{\circ}$ & $43.07^{\circ}$ & $45.23^{\circ}$ & $44.17^{\circ}$ & $42.22^{\circ}$ & $41.34^{\circ}$ & $39.52^{\circ}$ \\
\hline 1.62 & $31.54^{\circ}$ & $42.22^{\circ}$ & $43.63^{\circ}$ & $42.51^{\circ}$ & $39.83^{\circ}$ & $39.20^{\circ}$ & $38.89^{\circ}$ \\
\hline 1.57 & $30.02^{\circ}$ & $41.34^{\circ}$ & $42.51^{\circ}$ & $40.75^{\circ}$ & $37.59^{\circ}$ & $36.93^{\circ}$ & $36.26^{\circ}$ \\
\hline
\end{tabular}

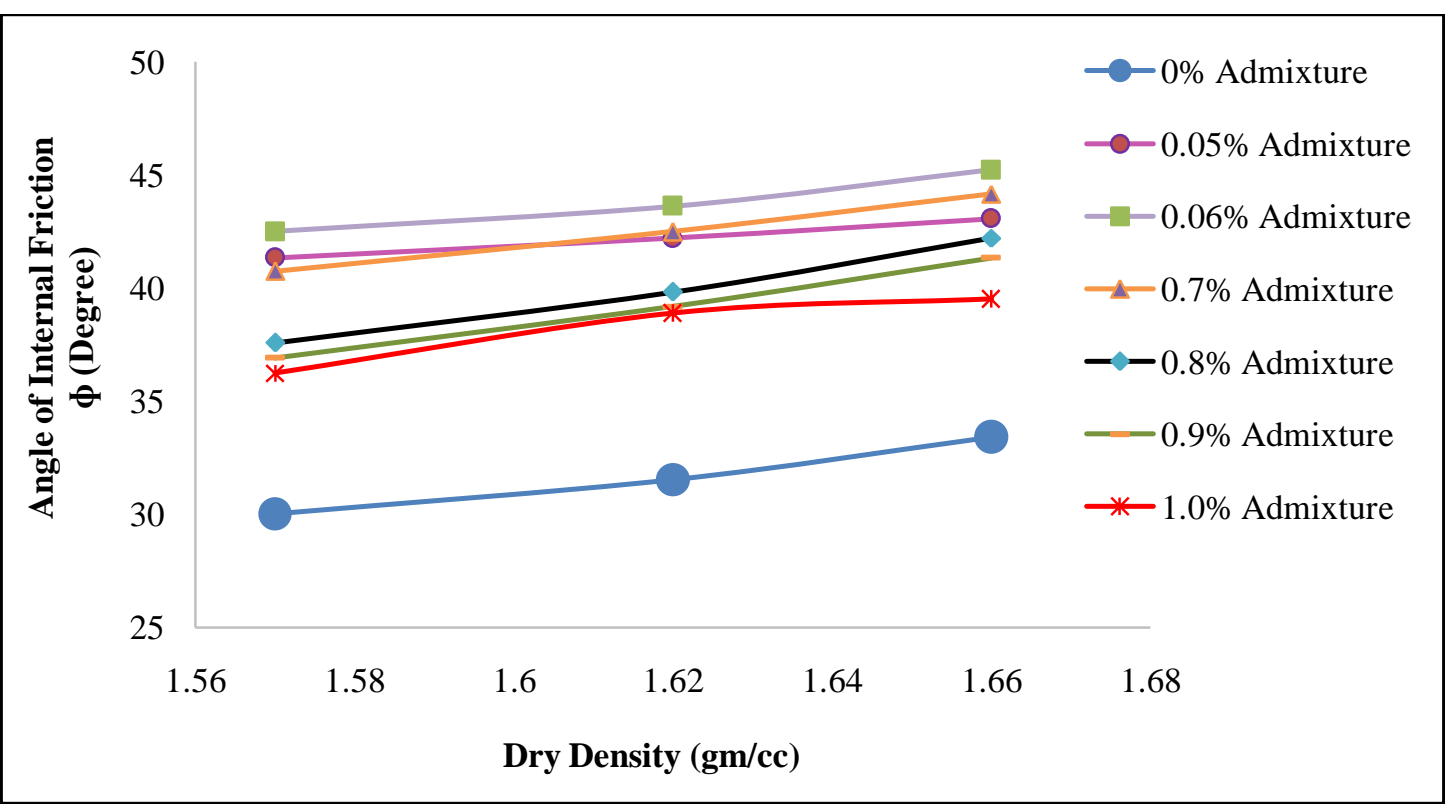

Figure 7:- Variation of $\phi$ with Dry Density of Sand and \% Admixture.

\section{Falling Head Permeability Test:-}

The test was conducted in variable head permeameter according to IS 2720 (Part XVII). All the permeability tests were conducted on dune sand at MDD $1.66 \mathrm{gm} / \mathrm{cc}$, with LDPE waste content in varying percentage of $0 \%, 0.05 \%$, $0.06 \%, 0.7 \%, 0.8 \%, 0.9 \%$ and $1.0 \%$. Canal lining sheet of LDPE obviously has some tremendous water barrier properties. Coefficient of permeability for dune sand mixed with LDPE waste strips was determined to access effect of size and proportion of strips. Test results have been shown in Table 7 and in Fig. 8.

Table 7:- Falling Head Permeability Test at MDD $1.66 \mathrm{gm} / \mathrm{cc}$

\begin{tabular}{|c|c|c|}
\hline S. No. & Plastic Waste Content $(\%)$ & Coefficient of Permeability $(\mathrm{k})(\mathrm{cm} / \mathrm{sec})$ \\
\hline 1. & $0 \%$ & $2.42 \times 10^{-3}$ \\
\hline 2. & $0.05 \%$ & $2.23 \times 10^{-3}$ \\
\hline 3. & $0.06 \%$ & $2.18 \times 10^{-3}$ \\
\hline 4. & $0.7 \%$ & $1.61 \times 10^{-3}$ \\
\hline 5. & $0.8 \%$ & $1.50 \times 10^{-3}$ \\
\hline 6. & $0.9 \%$ & $1.38 \times 10^{-3}$ \\
\hline 7. & $1.0 \%$ & $1.27 \times 10^{-3}$ \\
\hline
\end{tabular}




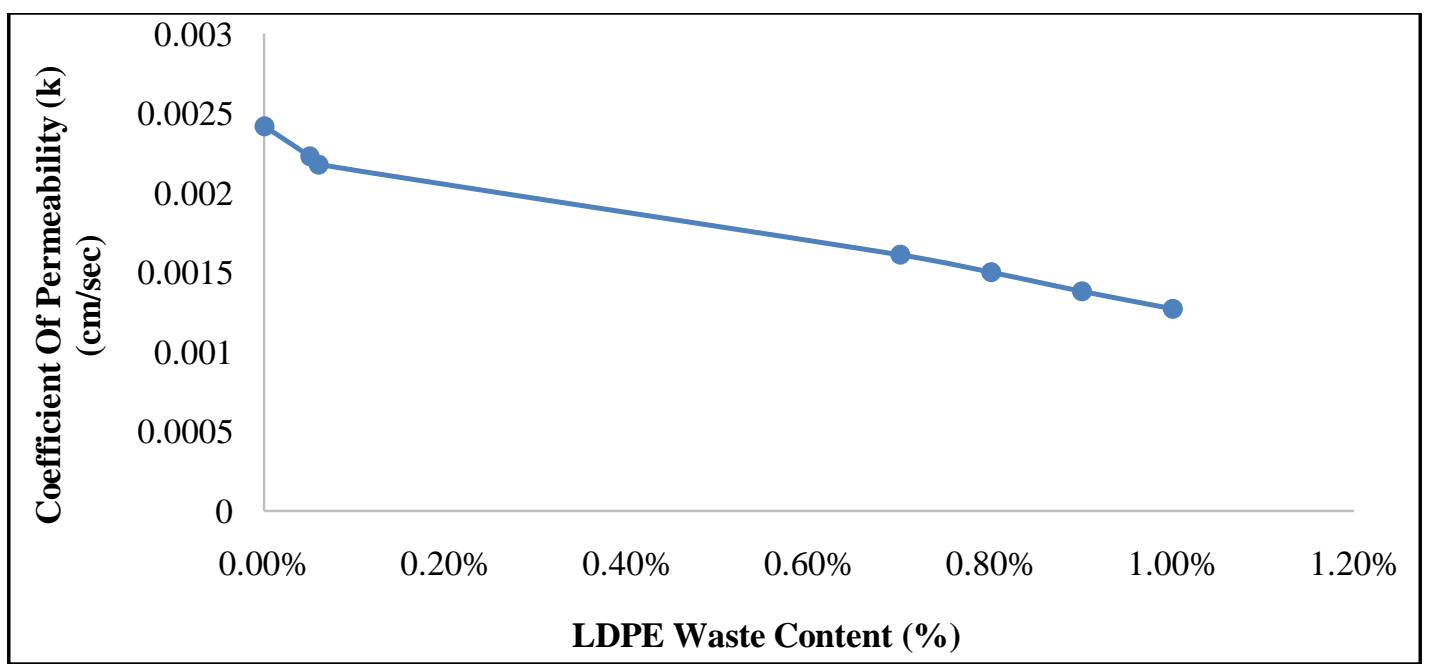

Figure 8:- Variable Head Permeability Test at MDD $1.66 \mathrm{gm} / \mathrm{cc}$.

\section{Conclusion:-}

In this investigation we have used LDPE strips as plastic waste in different proportions to study its effect on various geotechnical properties of dune sand of Western Rajasthan, India. Laboratory tests have been performed on LDPE waste strips of size $5 \mathrm{~mm}$ X $5 \mathrm{~mm}$ in various mix composition as $0 \%, 0.05 \%, 0.06 \%, 0.7 \%, 0.8 \%, 0.9 \%$, and $1.0 \%$ with dune sand. The dune sand condition has been simulated by keeping the dry densities $1.66 \mathrm{gm} / \mathrm{cc}, 1.62 \mathrm{gm} / \mathrm{cc}$ and $1.57 \mathrm{gm} / \mathrm{cc}$. The results of the testing program clearly show that the engineering properties of the dune sand improved considerably due to stabilizing using LDPE waste strips.

After analysis of the test results presented in the tables and figures, the following conclusion are drawn regarding the performed experimental study:

1. Angle of internal friction $(\phi)$ is initially increases with increase in percentage of LDPE waste strips and after that it decreases with increase in percentage of LDPE waste strips in the mix composition. Less percentage as $0.06 \%$ of LDPE waste gives optimum values.

2. Also at MDD $1.66 \mathrm{gm} / \mathrm{cc}$, the angle of internal friction $(\phi)$ is the highest $45.23^{\circ}$ among all other dry densities of dune sand mix with $0.06 \%$ of LDPE waste and that is $35 \%$ more than pure dune sand.

3. Shear strength increases with increasing amount of LDPE waste strips up to the optimum amount beyond which the gain in strength is smaller. The smaller grain size provides greater contact area and better surface frictional resistance between dune sand and LDPE waste strips.

4. The permeability of plain dune sand and LDPE waste strips mixed dune sand was determined. It can be concluded that the permeability reduces with an increase in the percentage of LDPE waste as the canal lining film has water barrier property. The value of coefficient of permeability is decreased by $47 \%$.

5. Results of tests demonstrated that inclusion of waste LDPE strips in soil will increase the stability of slopes as for reduced cross section of road embankment angle of internal friction is increased. For further studies, the aspect ratio of LDPE strip and percentages of LDPE can be changed.

\section{References:-}

1. Akash Gupta, Dr. N. K. Ameta, "Fine Sand Stabilization Using Sanitary Ware Waste as Admixture for Design of Flexible Pavement in Construction of Roads", AJER, Volume-5, Issue-8, 2016.

2. Akash Gupta, Dr. N. K. Ameta, "Stabilization of Fine Sand through Sanitary Ware Waste as Admixture for Construction of Embankments for Roads", IJIRSET, Vol. 5, Issue 8, August 2016.

3. Pragyan Bhattarai, A. V. A Bharat Kumar, K. Santosh, T. C. Manikanta and K. Tejeswini, "Engineering Behavior of Soil Reinforced With Plastic Strips," International Journal of Civil, Structural, Environmental and Infrastructure Engineering Research and Development (IJCSEIERD), ISSN 2249-6866 Vol. 3, Issue 2, PP.8388, Jun 2013, TJPRC Pvt. Ltd.

4. S. K. Tiwari, J. P. Sharma, "Characterization and Strength Improvement Techniques for Collapsible Dune Sands", EJGE Vol. 18, 2013.

5. Dr. Ameta N.K., Pratibha Panwar, "Stabilization of Dune Sand with Bentonite and Lime", EJGE, Vol. 18, 2013. 
6. Dr. N.K. Ameta, Dr. A. S. Wayal, Dr. D.G. M. Purohit, "Dune Sand Stabilization Using Bentonite and Lime", JERS Vol. III, Issue I, PP. 58-60, January-March, 2012.

7. Amol S. Bale, "Potential Reuse of Plastic Waste in Road Construction: A Review", April 2011.

8. Dr. N.K. Ameta, D.G. M. Purohit, and Wayal A.S., "Behavior of Square Footing on Dune Sand Reinforced with Nylon Fibre", International Journal of Geotechnical Engineering, Volume 3, Issue 2, pp. 313-317, April 2009.

9. Alam Singh, Basic Soil Mechanics and Foundation (CBS Publishers and Distributer, India, 2009).

10. Dr. N.K. Ameta and Abhay Shuvaji Wayal, "Effect of Bentonite on Permeability of Dune Sand", E.J.G.E., Vol. 13-Bund. A, 2008.

11. Overview of materials for Low Density Polyethylene (LDPE), Film Grade, MatWeb, Material Property Data. 